\title{
$S R Y$-related genes in the genome of the rice field eel (Monopterus albus)
}

\author{
Rongjia ZHOU ${ }^{\mathrm{a}, *}$, Hanhua CHENG ${ }^{\mathrm{a}}$, \\ Quiyang ZHANG ${ }^{\mathrm{b}}$, Yiqing GuO ${ }^{\mathrm{a}}$, Richard K. COOPER ${ }^{\mathrm{b}}$, \\ Terrence R. TIERSCH ${ }^{\mathrm{C}}$ \\ ${ }^{\text {a }}$ Department of Genetics and Center for Developmental Biology, \\ College of Life Sciences, Wuhan University, Wuhan 430072, PR China \\ ${ }^{\mathrm{b}}$ Department of Veterinary Science, Louisiana State University Agricultural Center, \\ Louisiana Agricultural Experiment Station, Baton Rouge, LA 70803, USA \\ c Aquaculture Research Station, Louisiana State University Agricultural Center, \\ Louisiana Agricultural Experiment Station, Baton Rouge, LA 70803, USA
}

(Received 4 December 2000; accepted 12 June 2001)

\begin{abstract}
The mammalian sex determining gene, $S R Y$, is the founding member of the new growing family of Sox (SRY-like HMG-box gene) genes. Sox genes encode transcription factors with diverse roles in development, and a few of them are involved in sex determination and differentiation. We report here the existence of Sox genes in the rice field eel, Monopterus albus, and DNA sequence information of the HMG box region of five Sox genes. The Sox1, Sox 4 and Sox 14 genes do not have introns in the HMG box region. The Sox 9 gene and Sox 17 gene, which each have an intron in the conserved region, show strong identity at the amino acid level with the corresponding genes of mammals and chickens. Similar structure and identity of the Sox 9 and Sox 17 genes among mammals, chickens and fish suggest that these genes have evolutionarily conserved roles, potentially including sex determination and differentiation.
\end{abstract}

fish / Sox / cloning / sex determination

\section{INTRODUCTION}

The identification of the testis-determining gene on the mammalian Y chromosome has been one of the recent breakthroughs of developmental biology. This gene, named "sex-determining region Y" $(S R Y)$ is responsible for initiating testis development during mammalian embryogenesis [1, 19, 20,25,27]. Sequence analysis of $S R Y$ demonstrated that it contains a 79 amino acid HMGbox which binds to DNA and bends it in a sequence-specific manner. Mutations in the HMG-box region, which alter the abilities of binding and bending, are

\footnotetext{
* Correspondence and reprints
}

E-mail: rjzhou@public.wh.hb.cn 
associated with sex reversal in XY females $[1,10,16]$. This suggests that $S R Y$ is involved in transcriptional regulation. The $S R Y$ gene belongs to a rapidly growing family of genes that are related by sequence homology to the HMG box, named Sox genes (SRY-like HMG-box gene). The members of the Sox gene family have been conserved through evolution, and have been found in a wide variety of species including humans [7], mice [36], marsupials [11], birds [14], turtles [26], Xenopus [23], alligators, lizards, Drosophila [6] and fishes $[12,15,29,30,32]$. Although recent studies show that some Sox genes have important developmental roles, many of them have not been identified. In the Sox gene family, besides $S R Y$ as the sex-determining gene in mammals, the Sox 9 gene is another candidate for the sex-determining gene, and also for cartilage formation, in mammals and chickens, and perhaps in some fishes [28] and alligators [35], although several rodent species do not possess these genes for their sex determination [2]. The Sox3 gene would be a candidate as an ancestor for the sex-determining gene $S R Y$ [13].

In contrast to those of mammals, the sex determining mechanisms of fishes are poorly characterized. Most species of fish lack heteromorphic sex chromosomes. Genes responsible for sex determination have not been identified, and little is known about the molecular genetics of sex determination. The rice field eel, Monopterus albus, which undergoes natural sex reversal from the female to male, could be informative for research of the labile sex-determining mechanisms of fishes. The rice field eel is also one of the most economically important freshwater fishes in East Asia. Fish producers desire all-male populations because the males grow faster and larger than females, and the males are also considered to taste better. We therefore investigated the existence, and DNA sequences of $S R Y$-related genes in the rice field eel to assist in developing methods for understanding and controlling sex phenotype in this species.

\section{MATERIALS AND METHODS}

\subsection{Experimental fish and DNAs}

Rice field eels were obtained from markets in the Wuhan area in China. Genomic DNA was isolated from whole blood cells, testis and ovaries by routine methods.

\subsection{Southern blot hybridization}

DNA of rice field eels was digested with the EcoRI restriction enzyme, electrophoresed on $0.8 \%$ agarose-TBE gels and transferred to Hybond-N filters in $10 \times$ SSC buffer. The probe, an $800 \mathrm{bp}$ fragment of the human $S R Y$ gene (including the HMG-box) was labeled with ${ }^{32} \mathrm{P}$, added to filters in hybridization buffer (5 mM EDTA, 0.25 M Na $2 \mathrm{HPO} 4 \mathrm{pH} 7.2,7 \%$ SDS) and hybridized for 
$16 \mathrm{~h}$ at $55^{\circ} \mathrm{C}$. The filters were washed using $2 \times$ SSC and $0.1 \%$ SDS at $55^{\circ} \mathrm{C}$ and using $0.5 \times \mathrm{SSC}$ and $0.5 \%$ SDS at $65^{\circ} \mathrm{C}$ before autoradiography was performed. Band sizes were estimated by using a $\lambda$ DNA HindIII size Marker.

\subsection{Degenerate PCR, cloning and sequencing analysis}

The primers for degenerate PCR were:

5'GATGGATCCATGAA(C/T)GC(A/T/C)TT

(C/T)AT(G/A/T)GT(A/G/T/C)GG3'

and

5'GCGCGAATTCGG(A/G/T/C)(C/T)(G/T)(A/G)TA

(C/T)TT(A/G)TA(A/G)T(C/T)(G/A/T)GG3'

which are the same as those reported by Denny et al. [7] but with our addition of restriction site sequences at the $5^{\prime}$ end of the primers. The genomic DNA from blood cells was used as template for PCR, and products from male DNA were cloned into pBluescript (Stratagene, La Jolla, CA) and sequenced using the Ready-Reaction Cycle Sequencing kit (Perkin Elmer) and an automated DNA sequencer (ABI 310 Genetic Analyzer, Perkin Elmer, CA). All nucleotide sequences were analyzed using the Sequence Navigator software (version 1.0.1, Perkin Elmer) to determine similarity with other Sox genes listed by the National Center for Biotechnology Information (http/www.ncbi.nih.gov). A phylogenetic tree was constructed with DNASIS software.

\section{RESULTS AND DISCUSSION}

\subsection{Southern blot analysis}

To determine whether genes homologous to $S R Y$ were present in the genome of the rice field eel, a probe containing an $800 \mathrm{bp}$ fragment of human $S R Y$ including the conserved HMG box domain was used in this study. The probe was hybridized to the EcoRI-digested genomic DNA from blood cells of male and female rice field eels. The probe identified a $3.2 \mathrm{~kb}$ fragment in both sexes, although a small gel shift in lane 9 was observed since different amounts of DNA loaded in the lane (Fig. 1a). At low stringency, another five bands were observed, but sex-related differences were not found. Since different chromosomal constitution between gonad and other tissues were observed in some species of the Peramelidae, Southern blot of rice field eel genomic DNA isolated from testis and ovaries was analyzed. Similar, $3.2 \mathrm{~kb}$ fragments were identified (Fig. 1a), which suggested that there was not a blockage of recombination in the $S R Y$-related genes during meiosis, or there would be the same genetic constitution between germinal and somatic cells. 


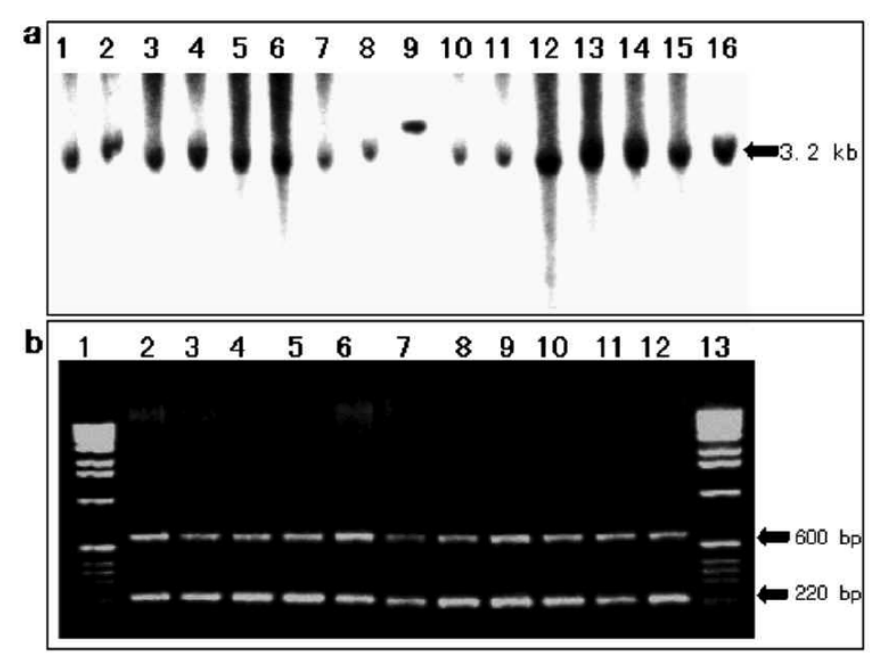

Figure 1. (a) Southern blot of genomic DNA from blood, testis and ovaries of 6 male and 5 female rice field eels after hybridization with a 800 bp human $S R Y$ probe including the conserved HMG box. Lanes 1-6, male, blood; 7-11, female, blood; 12-15, testis; 16, ovary. (b) DNA fragments amplified by PCR from genomic DNA of both sexes of the rice field eel with degenerate primers targeting Sox genes. Lanes 1 and 13, 1 kb DNA ladder; 2-6, male; 7-12, female.

\subsection{Isolation of $S R Y$-related genes}

To gain more information about the $S R Y$-related genes, especially Sox 9 and Sox 17, potentially involved in sexual development in rice field eels, genomic DNA was used as a target for PCR amplification using degenerate primers designed to target the conserved HMG box of SRY and Sox genes. The SOX 4 to -15 genes were obtained by using these pairs of primers [7]. Two different sizes of bands, $220 \mathrm{bp}$ and $600 \mathrm{bp}$, were observed in males and females (Fig. 1b). These two fragments from males were cloned and sequenced separately. For the $220 \mathrm{bp}$ fragment, three different Sox genes were found, which were designated Sox1, Sox 4 and Sox 14 (Fig. 2a) because they showed $96 \%, 96 \%$ and $94 \%$ identities at the amino acid level of the HMG box region with the corresponding Sox genes of the mouse by Blast search [31, 36]. Sox 4 of the rice field eel also showed $98 \%$ agreement with the amino acid sequence of the human SOX4 gene [9]. Sox genes play a variety of roles in development. Mouse Sox 1 is associated with the developing nervous system and urogenital ridge [5], and Sox4 has been shown to have a role in the regulation of lymphoid differentiation [9], while Sox14 is expressed in 15-dayold mouse embryos [36], which suggests important roles for these Sox genes in development. 


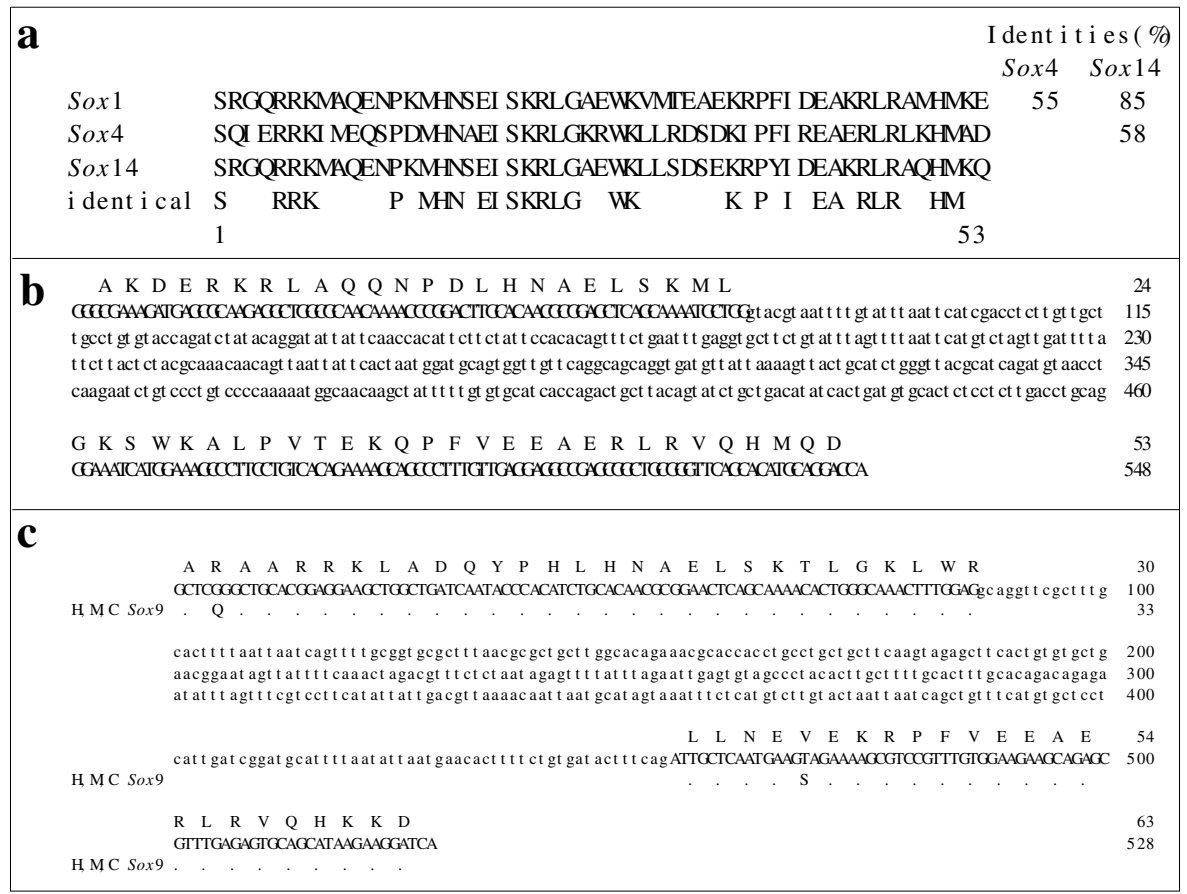

Figure 2. (a) Amino acid sequence comparison of the HMG-box region of Sox 1 , Sox4, and Sox 14 of the rice field eel. The numbers on the right show the identities (\%) among the Sox genes of the rice field eel. The GenBank accession numbers are Sox 1 , AF001043; Sox4, AF001044, and Sox14, AF001045. (b) The nucleotide sequence and deduced amino acid sequence of rice field eel Sox 17 . The intron is represented by the lower case. The GenBank accession number is AF001047. (c) The nucleotide sequence and deduced amino acid sequence of the rice field eel Sox 9 and comparison with Sox9 of humans, mice and chickens. Use of "." indicates the sharing of an amino acid among rice field eels, humans, mice and chickens; H, human; M, mice; C, chickens. The GenBank accession number is AF001046.

Because there is an intron in the HMG box region of both Sox 9 and Sox 17 of mammals, we cloned the $600 \mathrm{bp}$ fragment in order to search the orthologues of these genes of the rice field eel. Two different Sox genes were identified, which were more similar to Sox 9 and Sox 17 of mammals and chickens. The Blast search showed that the amino acid sequence of Sox 17 of the rice field eel was most close to ( $93 \%$ identical) the sequence of the HMG box of the mouse Sox 17 gene $[8,17]$. Interestingly, there was also an intron found in the HMG box of Sox 17 of rice field eel similar to the intron found in Sox 17 of the mouse at the same splicing site (Fig. 2b). The finding of similar structure between Sox 17 genes of the rice field eel and mammals suggests that this gene has conserved functions. Recent studies show that the mouse Sox 17 gene is expressed in 


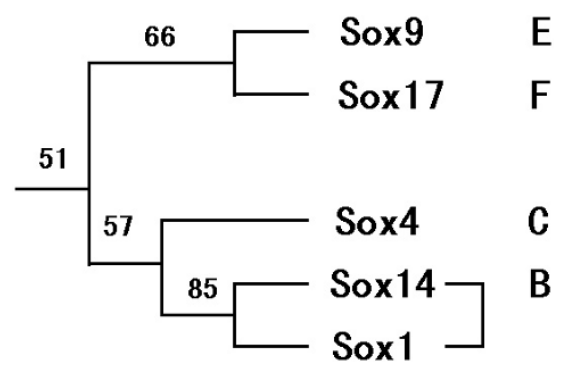

Figure 3. Phylogenetic tree of the rice field eel Sox genes. The number on the lines of roots show the amino acids identities (\%) among the Sox genes. Groups B, C, E and $\mathrm{F}$ are shown on the right.

spermatogonia and may function as a transcriptional activator in the premeiotic germ cells [17]. As in human Sox9, there was an intron in the HMG box region of Sox 9 of the rice field eel, and this gene showed $96 \%$ agreement in the amino acid sequence of the HMG box region with the Sox 9 of humans, mice and chickens by Blast search (Fig. 2c). In the HMG box region, there were only two amino acids which were different from the $\operatorname{Sox} 9$ gene of these species. The homologues of SOX9 from humans [11,33], mice [37], chickens [18,24], alligators, puffer fish [6,24], and rice field eels show a high level of protein conservation, which suggests that Sox 9 has conserved functions, potentially including sex determination.

These Sox genes of the rice field eel were organized in a phylogenetic tree based on their amino acid identities (Fig. 3). All Sox genes have been divided into seven A-G groups [34]. The Sox1 and Sox14 of the rice field eel belong to group B, Sox 4 to group C, while the related genes Sox 9 and Sox 17 fall into groups $\mathrm{E}$ and $\mathrm{F}$ respectively, which contain one intron interrupting their HMG domain encoding regions. The organization of the Sox family into seven groups suggests that each of these groups may have distinct and specific functions. To date, few reports have analyzed the specific function of individual Sox genes. Further studies will allow us to identify the functional differences that may exist between these Sox gene groups.

Natural sex reversal from females to males has been demonstrated in the rice field eel $[3,4,21,22]$. The successive events of natural sex reversal in the species were found to be genetically governed, although appropriate environmental factors also influenced the events. The genetic switch mechanism whereby the phenotype of the rice field eel is shifted from females to males must involve the expression of regulatory genes. Elucidation of this mechanism in this species could cast new light on the field of vertebrate sex determination and differentiation. There has not been any report concerning gene sequences involved in sex determination and differentiation in this species before the 
present work. The genes Sox 9 and Sox 17 could be candidates for regulatory genes in natural sex reversal in the rice field eel, since the homologues of Sox 9 and Sox 17 from a variety of species have conserved functions in sexual development, although they have other roles in development. It would be informative to further characterize these two genes and to clone the other genes involved in sex determination, such as DMRT1, for exploration of the sex determination and differentiation of this species.

\section{ACKNOWLEDGEMENTS}

We thank P. Berta for providing the human SRY probe and B. Smith for technical assistance in DNA sequencing. This work was supported by the Fok Ying Tung Education Foundation of China, and the National Natural Science Foundation of China, and the US Department of Agriculture.

\section{REFERENCES}

[1] Berta P., Hawkins J.R., Sinclair A.H., Taylor A., Griffiths B.L., Goodfellow P.N., Fellous M., Genetic evidence equating $S R Y$ and the testis-determining factor, Nature 348 (1990) 448-450.

[2] Baumstart A., Akhverdyan M., Schulze A., Reisert I., Vogel W., Just W., Exclusion of $S O X 9$ as the testis determining factor in Ellobius lutescens: Evidence for another testis determining gene besides SRY and SOX9, Mol. Genet. Metab. 72 (2001) 61-66.

[3] Bullough W.S., Hermaphroditism in the lower vertebrates, Nature 160 (1947) 9-11.

[4] Chan S.T.H., Philips J.G., The structure of the gonad during natural sex reversal in Monopterus albus (Pisces: Teleostei), J. Zool. 151 (1967) 129-141.

[5] Collingnon J., Sockanathan S., Hacker A., Cochen-Tannoudji M., Norris D., Rastan S., Stevanovic M., Goodfellow P.N., Lovell-Badge R., A comparison of the properties of Sox-3 with Sry and two related genes, Sox-1 and Sox-2, Development 2 (1996) 509-520.

[6] Coriat A.M., Muller U., Harry J.L., Uwanogho D., Sharpe P.T., PCR amplification of $S R Y$-related gene sequences reveals evolutionary conservation of the $S R Y$-box motif, PCR Methods Appl. 2 (1993) 218-222.

[7] Denny P., Swift S., Brand N., Dabhade N., Barton P., Ashworth A., A conserved family of genes related to the testis determining gene, $S R Y$, Nucleic Acids Res. 20 (1992) 2887.

[8] Dunn T.L., Mynett-Johnson L., Wright E.M., Hosking B.M., Koopman P.A., Muscat G.E.O., Sequence and expression of Sox-18 encoding a new HMG-box transcription factor, Gene 161 (1995) 223-225.

[9] Farr C.J., Easty D.J., Ragoussis J., Collignon J., Lovell-Badge R., Goodfellow P.N., Characterization and mapping of the human SOX4 gene, Mamm. Genome 4 (1993) 577-584. 
[10] Ferrari S., Harley V.R., Pontiggia A., Goodfellow P.N., Lovell-Badge R., Bianchi M.E., $S R Y$, like HMG1, recognizes sharp angles in DNA, EMBO J. 11 (1992) 4497-4506.

[11] Foster J.W., Graves J.A., An SRY-related sequence on the marsupial X chromosome: implications for the evolution of the mammalian testis-determining gene, Proc. Nat. Acad. Sci. (USA) 91 (1994) 1927-1931.

[12] Fukada S., Tanaka M., Iwaya M., Nakajima M., Nagahama Y., The Sox gene family and its expression during embryogenesis in the telest fish, medaka (Oryzias latipes), Dev. Growth Differ. 4 (1995) 379-385.

[13] Graves J.A., Interaction between $S R Y$ and SOX genes in mammalian sex determination, Bioessays 20 (1998) 264-269.

[14] Griffiths R., The isolation of conserved DNA sequences related to the human sex-determining region Y gene from the lesser black-backed gull (Larus fuscus), Proc. Roy. Soc. London Ser. B Biol. Sci. 244 (1991) 123-128.

[15] Ito M., Ishikawa M., Suzuki S., Takamatsu N., Shiba T., A rainbow trout $S R Y$-type gene expressed in pituitary glands, FEBS Lett. 1 (1995) 37-40.

[16] Jager R.J., Anvert M., Hall K., Scherer G., A human XY female with a frame shift mutation in the candidate testis-determining gene SRY, Nature 348 (1990) 452-454.

[17] Kanai Y., Kanai-Azuma M., Noce T., Saido T.C., Shiroishi T., Hayashi Y., Yazaki K., Identification of two Sox 17 messager RNA isoforms, with and without the High Mobility Group box region, and their differential expression in mouse spermatogenesis, J. Cell Biol. 133 (1996) 667-681.

[18] Kent J., Wheatley S.C., Andrews J.E., Sinclair A.H., Koopman P., A malespecific role for SOX9 in vertebrate sex determination, Development 122 (1996) 2813-2822.

[19] Koopman P., Munsterberg A., Capel B., Vivian N., Lovell-Badge R., Expression of a candidate sex-determining gene during mouse testis differentiation, Nature 348 (1990) 450-452.

[20] Koopman P., Gubbay J., Vivian N., Goodfellow P., Lovell-Badge R., Male development of chromosomally female mice transgenic for $S R Y$, Nature 351 (1991) 117-121.

[21] Liem K.F., Sex reversalas a natural process in the synbranchiform fish Monopterus albus, Copeia 2 (1963) 301-312.

[22] Liu C.K., Rudimentary hermaphroditism in the synbranchoid eel, Monopterus albus (Zuiew), Sinensia 15 (1944) 1-8.

[23] Miyata S., Miyashita K., Hosoyama Y., SRY-related genes in Xenopus oocytes, Biochem. Biophys. Acta 1 (1996) 23-27.

[24] de Silva S.M., Hacker A., Harley V., Goodfellow P., Swain A., Lovell-Badge R., Sox 9 expression during gonadal development implies a conserved role for the gene in testis differentiation in mammals and birds, Nat. Genet. 14 (1996) 62-68.

[25] Sinclair A.H., Berta P., Palmer M.S., Hawkins J.R., Griffiths B.L., Smith M.J., Foster J.W., Frischauf A.M., Lovell-Badge R., Goodfellow P.N., A gene from the human sex-determining regionencodes a protein with homology to a conserved DNA-binding motif, Nature 346 (1990) 240-244. 
[26] Spotila L.D., Kaufer N.F., Theriot E., Ryan K.M., Penick D., Spotila J.R., Sequence analysis of the ZFY and Sox genes in the turtle, Chelydra serpentina, Mol. Phylogenet. Evol. (1994) 1-9.

[27] Su H., Lau Y-F.C., Identification of the transcriptional unit, structural organization, and promoter sequence of the human sex-determining region Y (SRY) gene, using a reverse genetic approach, Am. J. Hum. Genet. 52 (1993) 24-38.

[28] Takamatsu N., Kanda H., Ito M., Yamashita A., Yamashita S., Shibat T., Rainbow trout Sox9: cDNA cloning, gene structure and expression, Gene 20 (1997) 167170.

[29] Tiersch T.R., Mitchell M.J., Wachtel S.S., Studies on the phylogenetic conservation of the $S R Y$ gene, Hum. Genet. 87 (1991) 571-573.

[30] Tiersch T.R., Simco B.A., Davis K.B., Wachtel S.S., Molecular genetics of sex determination in channel catfish: studies on $S R Y, \mathrm{ZFY}, \mathrm{Bkm}$, and human telomeric repeats, Biol. Reprod. 47 (1992) 185-192.

[31] Van de Wetering M., Oosterwegel M., van Norren K., Clevers H., Sox-4, an $S R Y$-like HMG box protein, is a transcriptional activator in lymphocytes, EMBO J. 12 (1993) 3847-3854.

[32] Vriz S., Lovell-Badge R., The zebrafish Zf-Sox 19 protein: A novel member of the Sox family which reveals highly conserved motifs outside of the DNA-binding domain, Gene 2 (1995) 275-276.

[33] Wagner T., Wirth J., Meyer J., Zabel B., Held M., Zimmer J., Pasantes J., Bricarelli F., Keutel J., Hustert E., Wolf U., Tommerup N., Schempp W., Autosomal sex reversal and campomelic dysplasia are caused by mutations in and around the $S R Y$-related gene Sox9, Cell 79 (1994) 1111-1120.

[34] Wagner M., From head to toes: The multiple facets of Sox proteins, Nucleic Acids Res. 27 (1999) 1409-1420.

[35] Western P.S., Harry J.L., Graves J.A., Sinclair A.H., Temperature-dependent sex determination: upregulation of SOX9 expression after commitment to male development, Dev. Dyn. 214 (1999) 171-177.

[36] Wright E.M., Snopek B., Koopman P., Seven new members of the Sox gene family expressed during mouse development, Nucleic Acids Res. 21 (1993) 744.

[37] Wright E., Hargrave M.R., Christiansen J., Cooper L., Kun J., Evans T., Gangadharan U., Greenfield A., Koopman P., The SRY-related gene Sox 9 is expressed during chondrogenesis in mouse embryos, Nat. Genet. 1 (1995) 15-20.

To access this journal online: www.edpsciences.org 